\title{
On a new stereospondylomorph temnospondyl from the Middle-Late Permian of Southern Brazil
}

\author{
Adriana Strapasson, Felipe L. Pinheiro, and Marina B. Soares \\ Acta Palaeontologica Polonica 60 (4), 2015: 843-855 doi:http://dx.doi.org/10.4202/app.00059.2014
}

A new temnospondyl is described from the Middle-Upper Permian sequence of the Paraná Basin (Rio do Rasto Formation) in southern Brazil. The material consists of disarticulated cranial and postcranial elements, preserved in association. The cranial elements include part of the orbital region of the skull roof, the basicranium, a number of endocranial elements, stapes and a right hemimandible. The postcranial elements include vertebrae, ribs, pectoral girdle elements, a right femur and a cluster of scales. The new species displays a rhinesuchid pattern, which is similar to the South African rhinesuchids from the Upper Permian Beaufort Group of the Karoo Basin, but differs from them by the presence of a robust and elongated epipterygoid with a blade-like anterior process in addition to elongated and deeper muscular pockets on the parasphenoid, which allow the assignment of this specimen to a new species. However, the phylogenetic analysis grouped the material described herein and Australerpeton cosgriffi inside Stereospondylomorpha, in a transitional position between the Laurasian assemblages and South African temnospondyls. This result supports a connection between the Brazilian and Eastern European Permian fauna and provides important data for future biostratigraphic studies.

Key words: Amphibia, Temnospondyli, Stereospondylomorpha, Permian, Rio do Rasto Formation, Brazil.

Adriana Strapasson [adriana.strapa@gmail.com] and Marina B. Soares [marina.soares@ufrgs.br ], Universidade Federal do Rio Grande do Sul, Setor de Paleovertebrados, Av. Bento Gonçalves, 9500 - Bloco J, Prédio 43127, Campus do Vale, CEP: 91509-900, Agronomia-Porto Alegre, Rio Grande do Sul, Brazil; Felipe L. Pinheiro [felipepinheiro@unipampa.edu.br], Laboratório de Paleobiologia, Universidade Federal do Pampa, Av. Antonio Trilha, 1847, São Gabriel, Rio Grande do Sul, Brazil. 
This is an open-access article distributed under the terms of the Creative Commons

Attribution License (for details please see creativecommons.org), which permits unrestricted use, distribution, and reproduction in any medium, provided the original author and source are credited.

For Full text $(1,978.5 \mathrm{kB})$ 